\title{
HUBUNGAN PENGETAHUAN DENGAN PERILAKU KESEHATAN GIGI DAN MULUT
}

\author{
Anang'), Hilmiy Ila Robbihi ${ }^{2)}$ \\ Jurusan Keperawatan Gigi, Politeknik Kesehatan Tasikmalaya, Tasikmalaya, Indonesia \\ email: anang@dosen.poltekkestasikmalaya.ac.id
}

\begin{abstract}
Abstrak
Tingginya prevalensi penyakit gigi dan mulut disebabkan oleh berbagai faktor, antara lain: pengetahuan, sikap dan perilaku dalam memelihara kesehatan gigi yang masih rendah. Hasil survey yang dilakukan pada mahasiswa baru jurusan Keperawatan Gigi, diperoleh sebanyak 30 orang memiliki penyakit gingivitis. Tujuan penelitian ini untuk mengetahui hubungan pengetahuan dengan perilaku kesehatan gigi dan mulut mahasiswa DIII tingkat 1 jurusan Keperawatan Poltekkes Kemenkes Tasikmlaya tahun akademik 2019/2020. Jenis penelitian yang digunakan adalah deskriptif analitik. Untuk pengujian hipotesis digunakan uji korelasi product moment untuk melihat hubungan antara variabel bebas dan terikat. Subjek dalam penelitian ini adalah seluruh mahasiswa tingkat I Diploma III Jurusan Keperawatan Poltekkes Kemenkes Tasikmalaya Tahun Akademik 2019/2020 berjumlah 79 orang. Instrumen penelitian terdiri dari angket pengetahuan dan perilaku yang dibuat dalam google form. Hasil Penelitian menunjukkan tingkat pengetahuan tentang kesehatan gigi mayoritas baik sebanyak 38 orang (51\%), cukup 36 orang (49\%) dan tidak ada yang termasuk kategori kurang (0). Perilaku mahasiswa tentang kesehatan gigi dan mulut mayoritas baik sebanyak 68 orang (92\%), cukup 6 orang (8\%) dan tidak ada yang termasuk perilaku kurang, nilai signifikansi 0,038 $<0,05$ dengan demikian dapat simpulkan terdapat hubungan pengetahuan dengan perilaku kesehatan gigi dan mulut.
\end{abstract}

Kata kunci : pengetahuan, perilaku kesehatan gigi dan mulut

\begin{abstract}
The high prevalence of oral and dental diseases is caused by various factors: knowledge, attitudes and behavior in maintaining dental health which are still low. The survey conducted on new students majoring in dental nursing showed that 30 people had gingivitis. The purpose of this study was to determine the relationship between knowledge and oral health behavior in DIII level 1 nursing students majoring in the Health Polytechnic of the Ministry of Health, Tasikmlaya in the 2019/2020 academic year. This type of research used descriptive analytic. To test the hypothesis, the product moment correlation test is used to see the relationship between the independent and dependent variables. The subjects in this study were all students of level I Diploma III Nursing Department of the Health Polytechnic of the Ministry of Health, Tasikmalaya, Academic Year 2019/2020, totaling 79 people. The research instrument consisted of a knowledge and behavior questionnaire made on by google form. The results of this study showed that the level of knowledge about dental health, the majority were good as many as 38 people (51\%), 36 people in sufficient category (49\%) and none were in the poor category $(0)$. The majority in oral health were in the good category 68 people (92\%), sufficient category 6 people (8\%) and noone was in lacking behavior. The significance value is obtained $0.038<0.05$, so there is a relationship between knowledge and oral health behavior.
\end{abstract}

Keywords : knowledge, oral health behavior

\section{PENDAHULUAN}

Kesehatan adalah hak asasi manusia dan sekaligus merupakan investasi sumber daya manusia, serta memiliki kontribusi yang besar untuk meningkatkan Index Pembangunan Manusia (IPM). Oleh karena itu menjadi suatu keharusan bagi semua pihak untuk memelihara, meningkatkan dan melindungi masyarakat Indonesia. Paradigma yang akan mengarahkan pembangunan kesehatan untuk lebih mengutamakan upaya peningkatan kesehatan (promotif) dan pencegahan penyakit atau masalah kesehatan (preventif), tanpa menyimpangkan upaya penanggulangan atau penyembuhan (kuratif) dan pemulihan (rehabilitatif) (Kemenkes RI, 2010). 
Pelayanan kesehatan yang bermutu dan merata harus dapat dijangkau oleh semua lapisan masyarakat serta dapat mendorong kemandirian untuk hidup sehat. Selain itu pemerataan pelayanan kesehatan diharapkan seluruh bangsa Indonesia memiliki derajat kesehatan yang optimal secara adil dan merata. Masalah kesehatan yang berkembang khususnya kesehatan gigi merupakan masalah yang sangat kompleks karena berkaitan dengan masalah di luar kesehatan itu sendiri. Pemecahan masalah kesehatan harus ditinjau dari berbagai faktor yang memengaruhi sehat atau sakit itu sendiri, baik individu, kelompok maupun masyarakat.

Salah satu faktor yang dapat memengaruhi pembangunan kesehatan yang optimal khususnya kesehatan gigi adalah tenaga kesehatan yang mampu melayani seluruh lapisan masyarakat. Sehingga mampu menciptakan manusia Indonesia yang sehat fisik dan mental untuk bekerja keras dan memiliki kemampuan produktifitas yang tinggi serta bekerja efektif dan efisien yang lebih menitik beratkan pada semua upaya untuk menciptakan manusia sehat demi meningkatkan derajat kesehatan gigi dan mulut (Kemenkes RI, 2010).

Kesehatan gigi dan mulut merupakan bagian penting dari kesehatan umum. Kesehatan gigi dan mulut yang buruk memiliki dampak negatif pada pertumbuhan dan perkembangan, membatasi aktifitas, produktifitas kerja, mengurangi kualitas hidup, dan kesejahteraan seseorang. Penyakit gigi dan mulut adalah salah satu penyakit kronis yang paling umum di seluruh dunia dan merupakan masalah kesehatan masyarakat yang utama karena menyebabkan beban kesehatan dan beban ekonomi pada individu, keluarga, masyarakat, dan sistem pelayanan kesehatan. Penyakit gigi dan mulut juga bisa mengakibatkan rasa sakit dan mengganggu fungsi sebagian anggota tubuh (WHO, 2016), (WHO, 2013). Kesehatan gigi dan mulut sering kali tidak menjadi prioritas utama bagi sebagian orang. Padahal, gigi dan mulut merupakan pintu gerbang masuknya kuman dan bakteri sehingga dapat mengganggu kesehatan organ tubuh lainnya (Kemenkes RI, 2010).

Kesehatan gigi dan mulut penting bagi kesehatan dan kesejahteraan tubuh secara umum dan sangat mempengaruhi kualitas kehidupan, termasuk fungsi bicara, pengunyahan dan rasa percaya diri. Gangguan kesehatan gigi dan mulut akan berdampak pada kinerja seseorang (Putri et al., 2010). Penyakit gigi dan mulut seperti karies gigi, penyakit periodontal, kehilangan gigi, lesi mukosa mulut, kanker oropharyngeal, manifestasi oral dari infeksi sistemik seperti HIV/AIDS, cacat bawaan dan trauma orodental merupakan masalah kesehatan masyarakat yang utama dan menjadi beban penyakit mulut di seluruh dunia (WHO, 2013)

Penelitian yang dilakukan di Afrika pada periode tahun 1990-2010 menunjukkan prevalensi karies gigi sangat tinggi mencapai 60\%-90\% terjadi pada anak-anak dan orang dewasa; pada periode tahun yang sama penyakit periodontal juga meningkat antara 68\%-75\% (WHO, 2013). Prevalensi karies gigi di Indonesia sampai tahun 2013 sudah mencapai angka 90,05\% terus berkembang seiring dengan bertambahnya umur (Hamid et al., 2017), (Marlita 2019), dan prevalensi penyakit periodontal sampai dengan tahun 2015 sudah mencapai angka 96,58\% pada penyakit gigi dan mulut (Wijaksana, 2016). Penyakit periodontal merupakan penyakit infeksi yang menyerang gusi (gingiva) dan jaringan pendukung gigi, apabila tidak dilakukan perawatan yang tepat akan mengakibatkan kehilangan gigi (Wijaksana, 2016). Penyakit periodontal dimulai dari penyakit gingivitis dan bila tidak dirawat akan berkembang menjadi periodontitis (Furoida, 2014)

Menurut Astuti, bahwa tingginya prevalensi penyakit gigi dan mulut pada umumnya disebabkan karena berbagai faktor, antara lain: faktor pengetahuan, sikap dan perilaku atau tindakan dalam memelihara kesehatan gigi yang masih rendah (Astuti, 2013). Pengetahuan merupakan dasar yang sangat penting terbentuknya tindakan seseorang. Pengetahuan tentang kesehatan gigi dan mulut yang kurang akan berpengaruh terhadap kondisi kesehatan gigi dan mulut seseorang. Pengetahuan merupakan hasil dari tahu, dan ini terjadi setelah orang melakukan pengindraan terhadap suatu objek tertentu (Notoatmodjo, 2010).

Pengetahuan yang kurang, sikap dan perilaku orang terhadap kesehatan gigi dan mulut juga, akan memengaruhi kondisi kesehatan gigi dan mulut seseorang. Sikap merupakan reaksi atau respons seseorang yang masih tertutup terhadap suatu stimulus atau objek, perilaku kesehatan pada dasarnya adalah respon seseorang terhadap stimulus atau objek yang berkaitan dengan sehatsakit, penyakit dan faktor-faktor yang mempengaruhi sehat-sakit (kesehatan) seperti lingkungan, makanan, minuman dan pelayanan kesehatan (Notoatmodjo, 2010) (Sodri, 2018).

Perilaku menyikat gigi yang salah dapat meningkatkan risiko terjadinya karies sebesar 20 kali. Perilaku menyikat gigi berkaitan dengan perilaku pemeliharaan kebersihan gigi dan mulut yaitu yang meliputi waktu menyikat gigi, frekuensi, alat serta cara menyikat gigi (Purwaningsih \& Sirat, 2016)(Sodri, 2018)

Hasil survei yang dilakukan di klinik Jurusan Keperawatan Gigi terhadap mahasiswa DIII 
Jurusan Keperawatan Gigi ditemukan bahwa sebanyak 30 dari 40 orang mahasiswa yang diperiksa terhadap mahasiswa baru tingkat satu memiliki penyakit gingivitis.

Tujuan penelitian ini untuk memberikan gambaran pengetahuan dan perilaku tentang kesehatan gigi dan mulut mahasiswa tingkat I Jurusan Keperawatan Poltekkes Kemenkes Tasikmalaya Tahun Akademik 2019/2020.

\section{METODE PENELITIAN}

Jenis penelitian yang digunakan adalah deskriptif analitik menggunakan uji korelasi product moment untuk melihat hubungan antara variabel bebas dengan terikat. Subjek dalam penelitian ini adalah seluruh mahasiswa tingkat I Diploma III Jurusan Keperawatan Poltekkes Kemenkes Tasikmalaya Tahun Akademik 2019/2020 yang berjumlah 79 orang. Instrumen penelitian terdiri dari angket pengetahuan dan perilaku yang dibuat dalam google form.

\section{HASIL DAN PEMBAHASAN}

Hasil penelitian mengenai pengetahuan mahasiswa DIII tingkat satu Jurusan Keperawatan Poltekkes Tasikmalalaya tentang kesehatan gigi dan perilaku dalam menjaga kesehatan gigi dan mulut, dapat dilihat pada tabel berikut:

Tabel 1. Karakteristik Responden berdasarkan Pengetahuan dan Perilaku dalam Menjaga Kesehatan Gigi dan Mulut

\begin{tabular}{|c|c|c|c|}
\hline No. & Karakteristik & Jumlah (orang) & Persentase $(\%)$ \\
\hline \multirow[t]{4}{*}{1.} & Pengetahuan tentang kesehatan gigi dan mulut & & \\
\hline & Baik & 38 & 51 \\
\hline & Cukup & 36 & 49 \\
\hline & Kurang & 0 & 0 \\
\hline \multirow[t]{4}{*}{2.} & Perilaku dalam menjaga kesehatan gigi dan mulut & 68 & 92 \\
\hline & Baik & 6 & 8 \\
\hline & Cukup & 0 & 0 \\
\hline & Kurang & & \\
\hline
\end{tabular}

Berdasarkan tabel 1 terlihat pengetahuan mahasiswa tentang kesehatan gigi sebagian besar, (51\%) termasuk kategori baik. Tabel 1 juga menginformasikan bahwa sebagian besar perilaku mahasiswa dengan kategori baik sebanyak 68 orang

Tabel 2. Persentase Pengetahuan dan Perilaku Mahasiswa tentang Kesehatan Gigi

\begin{tabular}{cccccc}
\hline No & Kategori & Pengetahuan (orang) & $(\%)$ & Perilaku (orang) & $(\%)$ \\
\hline 1 & Baik & 38 & 51 & 68 & 92 \\
2 & Cukup & 36 & 49 & 6 & 8 \\
3 & Kurang & 0 & 0 & 0 & 0 \\
\hline \multicolumn{2}{r}{ Total } & 74 & 100 & 74 & 100 \\
\hline
\end{tabular}

Berdasarkan tabel 2 menunjukkan persentase kategori baik lebih didominasi oleh perilaku mahasiswa yaitu sebanyak 68 orang (92\%), dan untuk kategori cukup paling banyak pada pengetahuan. Setelah dilakukan analisis deskriptif kemudian dilakukan uji hipotesis menggunakan uji korelasi product moment, hasilnya sebagai berikut:

Tabel 3. Uji Hipotesis

\begin{tabular}{|c|c|c|c|}
\hline & & Pengetahuan & Perilaku \\
\hline \multirow{3}{*}{ Pengetahuan } & Pearson Correlation & 1 & .414 \\
\hline & Sig. (2-tailed) & 1. & .038 \\
\hline & $\mathrm{N}$ & 74 & 74 \\
\hline \multirow{3}{*}{ Perilaku } & Pearson Correlation & .414 & 1 \\
\hline & Sig. (2-tailed) & .038 & 1. \\
\hline & $\mathrm{N}$ & 74 & 74 \\
\hline
\end{tabular}


Hasil tersebut memperlihatkan bahwa nilai signifikansi $0,038<0,05$ sehingga terdapat hubungan antara pengetahuan dengan perilaku kesehatan gigi dan mulut. Pengetahuan yang dimiliki seseorang dipengaruhi oleh berbagai faktor diantaranya tingkat pendidikan, semakin tinggi tingkat pendidikan semakin luas juga pengetahuan yang didapat. Pernyataan tersebut sesuai dengan pendapat Mubarak (2012) yang menyatakan bahwa Pendidikan mempengaruhi proses belajar, makin tinggi pendidikan seseorang makin mudah orang tersebut untuk menerima informasi. Seseorang dengan pendidikan tinggi akan cenderung untuk mendapatkan informasi baik dari orang lain maupun dari media massa, semakin banyak informasi yang masuk semakin banyak pula pengetahuan yang didapat tentang kesehatan.

Menurut hasil penelitian mengenai gambaran pengetahuan mahasiswa jurusan keperawatan tentang kesehatan gigi menunjukkan bahwa 38 orang atau $51 \%$ kategori pengetahuannya baik dan tidak ada yang memiliki pengetahuan kurang. Hasil tersebut menunjukkan bahwa mahasiswa baru telah berhasil memperoleh, mengingat dan memahami informasi dari apa yang dilihat dan didengar mengenai karies gigi serta telah mengetahui cara menjaga kebersihan gigi yang baik. Pendidikan sangat berhubungan erat dengan pengetahuan, terutama pengetahuan tentang kesehatan.

Hasil penelitian tersebut sesuai dengan hasil penelitian Rahtyanti et.al 2018 yang menyatakan bahwa mahasiswa baru Fakultas Kedokteran Gigi Universitas Jember tahun akademik 2016/2017 memiliki distribusi pengetahuan kesehatan gigi dan mulut paling banyak pada kategori baik.

Pengetahuan tentang kesehatan gigi dan mulut diartikan sebagai informasi tentang kesehatan gigi dan mulut yang diyakini kebenarannya. Keyakinan berdampak pada individu secara subyektif dapat menerima suatu obyek atau tindakan tertentu dan akibat dari tindakan tersebut. Pengetahuan merupakan salah satu faktor individu yang dapat mempengaruhi dan menentukan perilaku seseorang untuk melakukan upaya agar dapat mengurangi resiko dari ancaman masalah kesehatan (Purwaningsih \& Sirat, 2016).

Ada beberapa langkah pencegahan yang merupakan implementasi pengetahuan kesehatan gigi dan mulut yaitu memelihara kebersihan gigi dan mulut dengan cara menyikat gigi setiap hari setelah makan dan sebelum tidur dengan cara yang baik dan benar, menggunakan pasta gigi yang mengandung fluor. Mengatur pola makan dan melakukan pemeriksaan gigi berkala setiap 6 bulan sekali ke dokter gigi atau puskesmas (Ibrahim, 2018), (Senjaya, 2016).

Hasil penelitian mengenai perilaku mahasiswa tentang kesehatan gigi dan mulut mayoritas termasuk kategori baik sebanyak 68 responden (92\%), kategori cukup 6 orang dan tidak ada kategori perilaku yang kurang. Hasil penelitian mengenai perilaku mahasiswa lebih banyak kategori baik, dikarenakan perilaku tersebut sudah terbentuk sejak kecil hingga dewasa dan perilaku tersebut sudah diadopsi dari orangtuanya.Pada tahap adopsi ini, orang akan yakin dan telah menerima bahwa informasi baru berupa menggosok gigi memberi keuntungan bagi dirinya sehingga menggosok gigi menjadi kebutuhan. Namun, dari sebuah penelitian menyimpulkan bahwa perubahan perilaku tidak selalu melewati tahap-tahap. Apabila penerimaan perilaku baru atau adopsi perilaku melalui proses seperti ini didasari oleh pengetahuan, kesadaran dan sikap yang positif, maka perilaku tersebut akan bersifat lebih lama (long lasting). Sebaliknya perilaku yang tidak didasari oleh pengetahuan dan kesadaran tidak akan berlangsung lama (Palupi, 2013), (Monintja, 2015). Perubahan perilaku dapat terjadi secara alamiah, yaitu perubahan karena pengaruh lingkungan dan perubahan secara sengaja dan sistematis yaitu melalui pendidikan. Proses perubahan secara alamiah lebih lambat daripada proses pendidikan.

\section{KESIMPULAN DAN SARAN}

Hasil penelitian perilaku mahasiswa DIII tingkat 1 Jurusan Keperawatan Poltekkes Tasikmalaya, menunjukan mayoritas perilaku mahasiswa termasuk kategori baik sebanyak 68 orang atau (92\%), kategori cukup 6 orang (8\%), terdapat hubungan antara pengetahuan dengan perilaku mahasiswa DIII tingkat 1 jurusan keperawatan Polteknik kemenkes Tasikmalaya tahun Akademik 2019/2020.

Perlu adanya penelitian lanjutan mengenai hubungan pengetahuan kesehatan dengan perilaku dari aspek psikologi mahasiswa seperti motivasi dan kemandirian mahasiswa sehingga penelitian ini lebih berkembang.

\section{REFERENSI}

Astuti, N. R. (2013). Promosi kesehatan gigi dan mulut dengan metode ceramah interaktif dan demonstrasi disertai alat peraga pada Guru Sekolah Dasar sebagai fasilitator. Insisiva Dental Journal: Majalah Kedokteran Gigi Insisiva, 2(2), 16-26. 
Furoida, Y. (2014). Identifikasi Warna Koloni Bakteri Anaerob Pada Gingival Crevicular Fluid Pasien Gingivitis dan Periodontitis Kronis (Identification of Anaerobic Bacteria Colonies Color In Gingival Crevicular Fluid Of Gingivitis and Chronic Periodontitis Patients).

Hamid, S. A., Kundre, R., \& Bataha, Y. (2017). Hubungan pola makan dengan karies gigi pada anak kelas IV usia 8-9 tahun di SD Negeri 126 Manado lingkungan 1 kleak Kecamatan Malalayang kota Manado provinsi Sulawesi Utara. JURNAL KEPERAWATAN, 5(2).

Ibrahim, I., \& Roni, R. (2018). Implementasi Manajemen Promosi Kesehatan Dalam Menurunkan Angka Karies Gigi Pada Anak. JIKI Jurnal Ilmiah Kesehatan IQRA, 6(2), 95-103.

Kemenkes RI. (2010). Kebijakan Nasional Promosi Kesehatan. Jakarta: Kemenkes RI.

Marlita, L., \& Monalisa, M. (2019). Hubungan Pengetahuan Pada Siswa/i Kelas V Tentang Oral Hygiene Dan Pola Makan Terhadap karies gigi di SDN 99 Kecamatan Sukajadi Kecamatan Pekanbaru. Jurnal Ilmiah Fisioterapi (JIF), 2(2), 51-56.

Monintja, T. C. N. (2015). Hubungan antara karakteristik individu, pengetahuan dan sikap dengan tindakan PSN DBD masyarakat Kelurahan Malalayang I Kecamatan Malalayang Kota Manado. Jikmu, 5(5).

Mubarok, W.I.(2012). Metodologi penelitian kesehatan. Jakarta:rineka cipta.

Notoatmodjo, S. (2010). Metodologi penelitian kesehatan. Jakarta: rineka cipta.
Palupi, D. L. M. (2013). Pengaruh Pendidikan Kesehatan Terhadap Perubahan Pengetahuan, Sikap dan Perilaku Penderita Tuberculosis yang Berobat di Wilayah Kerja Puskesmas Surakarta. UNS (Sebelas Maret University).

Purwaningsih, P. P., \& Sirat, N. I. (2016). Analisis Faktor Resiko Yang Mempengaruhi Karies Gigi Pada Anak SD Kelas V-VI di Kelurahan Peguyangan Kangin. Analisis Faktor Resiko Yang Mempengaruhi Karies Gigi Pada Anak SD Kelas V-VI Di Kelurahan Peguyangan Kangin, 4(1).

Putri, M. H., Herijulianti, E., \& Nurjannah, N. (2010). Ilmu pencegahan penyakit jaringan keras dan jaringan pendukung gigi. Jakarta: EGC, 25.

Senjaya, A. A. (2016). Gigi lansia. Jurnal Skala Husada: The Journal of Health, 13(1).

Sodri, J. A. (2018). Hubungan Pengetahuan, Sikap Dan Tindakan Kesehatan Gigi Dan Mulut Dengan Status Kebersihan Rongga Mulut Perokok (Tinjauan pada Siswa SMA/Sederajat di Kota Banjarbaru). Dentin, 2(1).

WHO. (2013). Strategy For Oral Health In South-East Asia, 2013-2020.

WHO. (2016). Regional Oral Health Strategy 20162025:Addressing Oral Disease As Part Of Noncommunicable Diseasae.

Wijaksana, I. K. E. (2016). Infectobesity dan periodontitis: hubungan dua arah obesitas dan penyakit periodontal. ODONTO: Dental Journal, 3(1), 67-73.

Rahtyanti, at all. (2018). "hubungan pengetahuan Kesehatan Gigi dan Mulut dengan Karies Gigi pada Mahasiswa Baru Fakultas Kedokteran Gigi Universitas Jember tahun Akademik 2016/2017 (Correlation of Oral). 